\title{
Long-Term Effectiveness of the Hong Kong Employees Retraining Programme
}

William Chan

Wing Suen

School of Economics and Finance

The University of Hong Kong

April 2000

Correspondence can be sent to: William Chan, School of Economics and Finance, University of Hong Kong, Pokfulam Road, Hong Kong. Tel: (852)2859-1055; fax: (852)2548-1152; email:wchan@econ.hku.hk 


\begin{abstract}
The Employees Retraining Programme, launched by the Hong Kong government in 1992, was promoted as the solution to structural unemployment resulting from rapid transformation of the economy. However, our study of the labour market performance of a group of trainees who received skills training in 1994/5 shows no evidence of any positive effect on the earnings, days of employment, employment rate or unemployment rate of trainees more than three year after the completion of training when compared to a group of job searchers. In particular, full-time training is found to be less effective than part-time training, and training in general skills (language, computer and office skills) is significantly less effective than training in specific occupational skills. This suggests problems in the design and implementation of retraining in Hong Kong. The Programme has yet to fulfill its rather lofty promise.
\end{abstract}




\title{
Long-Term Effectiveness of the Hong Kong Employees Retraining Programme
}

\author{
William Chan and Wing Suen
}

\section{Introduction}

Global changes in the economic environment have resulted in significant changes in labor markets throughout the world. In developed economies, trade liberalization and technological and organizational changes have reduced the demand for unskilled labor relative to the demand for skilled labor. Workers without the requisite labor market skills find that they are increasingly lagging behind as the economy moves toward more knowledgeintensive modes of operation. In the United States, this is manifested in stagnant wage growth among people with low levels of education and little experience (Juhn, Murphy, and Pierce 1993), and in declining labor market participation among the less skilled workers (Juhn 1992). In continental Europe, unskilled labor do not experience a substantial relative wage decline, but this has come at the cost of high unemployment (Katz, Loveman, and Blanchflower 1995; Blau and Khan 1996).

The same set of economic forces have influenced Hong Kong as well. And because of its close proximity to the rapidly evolving economy of China, the pace of economic restructuring in Hong Kong is particularly fast. Skill-biased technical change coupled with the relocation of factories to China (and, to a lesser extent, the steady flow of low skilled Chinese immigrants into the territory) have created some strain on the less skilled workers in Hong Kong. There is evidence that wage inequality has been widening since the mid-1980s (Suen 1995). Amid this environment, the Employees Retraining Programme was launched in 1992 by the Hong Kong government, with the mission to retrain displaced and unemployed workers who are the victims of economic transformation. 
The Employees Retraining Programme has expanded rapidly in size and scope over the years. By 1999, it has received capital injection from the government totaling HK\$1.6 billion. Employees retraining is touted as an important piece of public policy to deal with the side effects of global economic transformation. Recently, the government is also exploring other policy options that encourage continuous "learning for life," so that people can better adapt to the demands of a constantly changing world.

Despite the importance that the government attaches to employees retraining, there are few policy evaluations that measure the effectiveness of the programme. Based on a study of pre-training and post-training employment outcomes, Chan and Suen (1999) find no evidence of any positive effect on the earnings or employment rate of trainees one year after the completion of training relative to various comparison groups. That study consists of three waves of surveys conducted over a 14 month period between late 1995 and early 1997 . For this reason, it can only evaluate the short term effectiveness of employees retraining. For training courses that are designed to improve job search skills, the effects should be fairly immediate and a short term evaluation is adequate. For training courses that impart general or specific labor market skills, however, the effects may not be fully apparent in a 14-month period, and a longer term perspective is desirable. The present paper is an attempt to address this.

Following up on the earlier surveys, we conducted a fourth wave survey in early 1999 to study the employment outcomes of individuals who had received skills training from the Employees Retraining Programme during January1996. We expect that any long term benefits from skills training should become apparent three years after completion of training. Incidentally, in the intervening period between this fourth wave survey and the earlier surveys, Hong Kong was hit by the Asian Financial Crisis. As a result, Hong Kong was in a 
deep recession when the fourth survey was being conducted. Unemployment reached a high of 6.2 percent in the first quarter of 1999. The benefits from retraining are probably easier to detect in a slack labor market than in a tight labor market. Together with the earlier waves of survey, this latest survey should provide the basis for a more comprehensive evaluation of the effectiveness of employees retraining in Hong Kong.

\section{Methodology of Evaluation}

Hong Kong is not the only economy that has experienced rapid structural transformation, nor is it the first to adopt retraining as a solution. The extensive foreign experience in retraining and the subsequent need to assess the outcomes have given rise a large literature on manpower programme evaluation. Methodologically, these evaluations usually adopt one of two approaches: the experimental approach and the non-experimental approach.

The experimental approach involves random assignment of subjects to treatment and control groups. Because the two groups are otherwise identical except for sampling errors, simple comparison between the outcome measures of the two groups gives an estimate of the treatment effect. Examples of studies using this approach are Bell et al. (1987), Couch (1992), Burghardt et al. (1992) and Friedlander et al. (1993) . Despite its inherent methodological superiority, the use of the experimental approach has been the exception rather the rule in the evaluation literature. Experiments involve tight control over the assignment of subjects, with services and benefits being withheld from certain members of the target group. The ethical and political problems involved often make the experimental approach impracticable. This is surely the case in Hong Kong, where the retraining programme was introduced partly to pacify union opposition to labour importation. To deny training to a sizable proportion of 
those who seek assistance would not have been politically acceptable. Without the active support of the government or the training bodies, an experimental design is out of the question in our study.

The alternative by default is the non-experimental approach. This approach requires the selection of a comparison group that serves as a benchmark for the assessment of the performance of the treatment group. The problem is that it is very difficult to ensure comparability of the treatment and comparison groups. Even if the comparison subjects are chosen to closely match the observable characteristics of the treatment subjects, their different decisions on whether to seek training may imply unobservable and systematic differences between them. Indeed, LaLonde (1986) and Fraker and Maynard (1987) find that the assessment that would obtain from a non-experimental approach using comparison groups often does not replicate the benchmark results from a randomized experiment.

The non-experimental approach is also notorious for its sensitivity to assumptions, choice of comparison groups and control variables, and analytic methods. This is illustrated in Barnow's (1987) synthesis of six studies of effectiveness of training (Westat 1981, Bloom \& McLaughlin 1982, Bassi 1983, Geraci 1984, Dickenson, Johnson \& West 1986, and Finifter 1987). Using the same data set but different approaches to ensuring comparability between the treatment and comparison groups, these studies end up with a wide range of estimates, particularly for male subjects. Because the correct specification of the models of earnings and programme participation decision of the subjects is unknown, and arbitrary assumptions about the unobservables are not always testable, it is often difficult to choose among alternative estimates and methods.

Nevertheless, recent research (Ashenfelter 1978, Ashenfelter and Card 1985, Heckman and Robb 1985, Heckman and Hotz 1989 and Hotz 1992) shows that, if the data is 
rich enough, more sophisticated econometric models can be developed to overcome some if not all of the problems of a non-experimental strategy. In this study, we do not have enough data to take full advantage of these methodological innovations. However, the structure of our data does allow us some flexibility in controlling for differences between the treatment and comparison groups, and in testing the validity of our model specification. Moreover, the literature also suggests that the comparison group approach works reasonably well in replicating the experimental results for female subjects. With a predominantly female retrainee population in Hong Kong, we hope that the selection bias inherent in any choice of a comparison group will not in the end significantly compromise our results.

\section{The Empirical Model}

There are different indicators of effectiveness of a retraining programme. The Hong Kong government has focused almost entirely on the employment rate. This is contrary to the traditional emphasis on earnings gain as a measure of manpower programme effectiveness in the literature, particularly when the relationship between the two variables is weak (Gay and Borus 1980). Nevertheless, given that there may not be any single indicator that fully captures the effects of a retraining programme, we shall use a number of different labour market variables as outcome measures.

Suppose the labour market performance of subject $i$ in period $t$ can be captured by a measure $Y_{i t}$. In the empirical analysis, $Y_{i t}$ may refer to continuous variables, like labour earnings and duration of employment, or to discrete variables, like employment and unemployment status. Because of the different nature of the variables, they are modeled differently.

Consider labor earnings first. We assume that earnings are determined by the personal 
characteristics of the subject $\left(X_{i t}\right)$, by participation in retraining programme $\left(D_{i t}=1\right.$ if the subject has completed a retraining course by period $t$ ), and by a disturbance term $\varepsilon_{i t}$. This disturbance term may further be decomposed into three components: an individual-specific fixed effect $\alpha_{i}$ resulting from unobserved heterogeneity of the population, a time-specific effect $\eta_{t}$ that depends on aggregate economic conditions, and a random noise $u_{i t}$ with zero mean. We can write

$$
Y_{i t}=X_{i t} \beta_{1}+D_{i t} \delta_{1}+\alpha_{i}+\eta_{t}+u_{i t}
$$

If we only had information in the post-training period, an ordinary least squares estimate of equation (1) would produce a biased estimate of the training effect $\delta_{1}$, because the participation decision $D_{i t}$ is likely to be correlated with the individual fixed effect $\alpha_{i}$. For example, participants of retraining programmes may predominantly be people with preexisting labour market disadvantages, and this will tend to bias the estimate of $\delta_{1}$ downwards. Alternatively, participants may be more motivated for labour market success than nonparticipants are, and this will tend to bias the estimate of $\delta_{1}$ upwards. In principle, the bias can be solved by explicitly modeling the selection into retraining programmes. However, since the selection mechanism is still poorly understood, such an approach is fraught with mis-specification problems. Instead, we can make use of the panel structure of the data set to tackle the selection bias problem.

With a panel data set, equation (1) can be estimated directly by including a dummy $\left(D_{t}\right)$ for each cross section to capture the fixed time effect $\eta_{t}$, and a dummy $\left(D_{i}\right)$ for each subject to capture the individual-specific effect $\alpha_{i}$ and other presumably time invariant attributes (such as gender and possibly education):

$$
Y_{i t}=X_{i t}^{\prime} \beta_{1}+D_{i t} \delta_{1}+D_{i} \gamma_{1}+D_{t} \gamma_{2}+u_{i t}
$$


where $X_{i}^{\prime}$ includes only time varying components of $X_{i t}$. Since $D_{i t}$ is uncorrelated with the disturbance term $u_{i t}$, an ordinary least squares estimation of (2) using both pre-training and post training data should yield an unbiased estimate of $\delta_{1}{ }^{1}$

Different types of training programme may have different effects on different individuals. Therefore, in addition to equation (2), we also estimate the following equation:

$$
Y_{i t}=X_{i t}^{\prime} \beta_{1}+D_{i t}\left(C_{i} \theta_{1}\right)+D_{i} \gamma_{1}+D_{t} \gamma_{2}+u_{i t}
$$

In this alternative form, the training effect is no longer assumed to be the same for all individuals, but instead depends on a vector of personal and programme characteristics $C_{i}$. In estimating this model, we have defined the $C_{i}$ variables in terms of their deviation from the mean. Thus, the t-statistics for the programme participation dummy variable can be interpreted as a test for the "average" training effect.

Equation (1) can also be applied to the analysis of the effect of retraining on the number of days of employment within given periods. However, because the dependent variable is defined in terms of an employment outcome between two points in time, it does not have a panel data structure. In particular, we do not have information on pre-training employment duration, which precludes a before-and-after comparison using the fixed-effects model. Thus, equation (1) has to be estimated without the individual fixed effects $\alpha_{i}$ and the time effects $\eta_{t}$. Moreover, there are some subjects who had no employment experience at all within the specified period, so that days of employment is a censored variable. To account for censoring, equation (1) and the corresponding model with interaction terms are estimated

${ }^{1}$ Alternatively, equation (1) can be differenced and estimated. The individual fixed effect will be differenced out, and the difference between the time-specific effects will be absorbed into the constant, so that the error term will be uncorrelated with the regressors (see Ashenfelter 1978 and Heckman and Robb 1985). However, since we have more than two panels of data, we can gain efficiency by estimating equation (2). 
by a tobit procedure rather than by ordinary least squares.

The fixed-effects approach cannot be applied when the dependent variable is a binary variable such as employment or unemployment status. We use a random effects probit model to analyze this aspect of labour market performance. We let

$$
Y_{i t}^{*}=Z_{i t} \beta_{2}+D_{i t} \delta_{2}+\mu_{t}+v_{i t} \text {. }
$$

Subject $i$ is employed in time $t\left(Y_{i t}=1\right)$ if $Y_{i t}^{*} \geq 0$, and she is not employed $\left(Y_{i t}=0\right)$ if $Y_{i t}^{*}<0$. In this formulation, $Z_{i t}$ is a vector of observable personal characteristics. The common dependence on aggregate economic shocks is modeled by the time varying intercept $\mu_{t}$. Individual heterogeneity is modeled by the correlation of the disturbance term. That is, for any two time periods $t$ and $t^{\prime}$, we let $\operatorname{corr}\left(v_{i t}, v_{i t}\right)=\rho$. Note that $D_{i t}=1$ if subject $i$ has completed treatment by period $t$, and $D_{i t}=0$ if subject $i$ belongs to the comparison group or if subject $i$ has not received treatment yet. Such within-individual variation in the participation dummy helps identify the treatment effect parameter $\delta_{2}$. As in the model of earnings, the treatment effect can interact with personal and programme characteristics. Thus, the following specification is also estimated:

$$
Y_{i t}^{*}=Z_{i t} \beta_{2}+D_{i t}\left(C_{i} \theta_{2}\right)+\mu_{t}+v_{i t} \text {. }
$$




\section{The Data}

The Employees Retraining Board (ERB) was set up in 1992 to implement the government retraining programme in Hong Kong. Its role is strictly one of financing, providing funding for approved courses conducted at many different locations in the territory by over fifty training bodies. A variety of training courses are funded. In the fiscal year 1995/6, some 60,000 persons completed courses financed by the ERB. Of these, 12 percent attended core courses on job search skills. However, the majority of the trainees ( 80 percent) enrolled in skills courses, which typically last more than one month and which can be either part-time or full-time. In 1995/6, 16 percent of the retrainees received training in job-specific skills, while another 64 percent were trained in general skills courses (primarily language or computer skills). This study focuses on these skills trainees.

Data for this study are collected in successive waves of survey, tracking the performance and characteristics of subjects over the course of 40 months. The treatment group consists of subjects who were receiving skills training during the first sampling period, in the last two weeks of January 1996. The unit of sampling was the course. The skills training treatment group was selected from a randomized list of skills courses included in the ERB brochure published in November 1995. To be included, a skills course had to be in session during the baseline sampling period. ${ }^{2}$ The courses were stratified by full-day and parttime courses, with the ratio of sampled courses in rough accordance with the distribution of course offerings by types of training. The skills-trainee subjects represent approximately a 20 percent sample of all trainees receiving skills training in January 1996. Baseline data on the treatment subjects were collected by having the trainees complete questionnaires distributed

\footnotetext{
${ }^{2}$ Because of logistic problems, courses offered in outlying islands and remote areas were dropped.
} 
during class meetings. Participation was voluntary. The breakdown of responding skills course trainees (with complete data throughout the longitudinal study) by types of training is shown in table 1.

Comparison subjects were drawn from individuals over age 30 who registered for job search assistance at offices of the Hong Kong Labour Department from December 11, 1995 to February 9, 1996. These individuals were either unemployed, or otherwise dissatisfied with their current employment. In this regard, they can be considered similar to the typical trainee. ${ }^{3}$ Those who agreed to participate in our study were interviewed over the telephone from midJanuary to mid-February. Unfortunately, we overestimated the response rate from these subjects, with the result that the size of the comparison group was significantly smaller than the treatment group (see table 2).

To gauge the effect of retraining on the labour market performance of the trainees, three follow-up surveys (the second, the third and the fourth wave) were conducted. The first follow-up survey, or the second wave, was implemented in May 1996. It covered only core (job search) course trainees and is irrelevant to the present study. The third wave was carried out from January to March 1997, while the fourth wave was implemented in April 1999. These last two surveys were conducted over the telephone and focused on the labour market

${ }^{3}$ Our choice of the comparison group also makes it less likely that the estimated training effect would be biased upward by the pre-programme dip in earnings of the trainees (see Ashenfelter 1978). Briefly, individuals enroll in manpower programmes often because of a transitory decrease in income, so that their earnings will tend to rebound over time, independent of any training effect. If the comparison group is drawn from administrative or census data, as in many U.S. studies, the trainees would be compared to individuals with better luck (and higher transitory income) on average at the baseline, even if they have the same earnings in the long run. This would tend to exaggerate the improvement brought about by training. Such is not the case in our study, since our comparison subjects were likely to have similar bad luck as the trainees at the time of the baseline survey. 
performance of skills subjects and their corresponding comparison group. Our data set is compiled from these two surveys as well as the baseline survey.

\section{Results}

\section{A. Comparison of characteristics and measures of performance}

Although we started off with a baseline sample of almost 1,000 treatment subjects and 400 comparison subjects, attrition over almost three and a half years has resulted in a significantly diminished sample by the time of the third follow-up survey of our study, when

only 674 treatment subjects and 185 comparison subjects were successfully interviewed. The reduction is particularly sharp for the comparison group because some of the subjects subsequently received retraining during the intervening years and had to be dropped. The characteristics of the remaining sample are summarized in table 2.

There are certain observable differences between the groups, most notably in gender composition. Skills trainees tend to be predominantly female, while the comparison group is more balanced in composition. The latter also tends to include significantly more recent immigrants and more family breadwinners. Otherwise, the groups are fairly well-matched on age, marital status, household composition, and work experience.

Estimates of the value-added of retraining can be derived from a comparison of measures of labour market performance of subjects at different points in time, and of their changes over time. This is summarized in table 3. Compared to job seekers who registered at the Labour Department, the skills trainees fared worse by almost all measures, both before and after they received retraining. Nevertheless, the trainees did show a larger improvement in employment and unemployment rates as well as in working hours, particularly over the long run: their unemployment rate dropped by almost 25 percentage points, and their 
employment increased by 20 percentage points three years after the completion of training, compared to the corresponding figures of 22 and 17 percentage points for the comparison group.

Other measures of performance are less encouraging. Relative to the comparison group, graduates of retraining courses worked 20 fewer days between January 1996 and March 1997, and 40 fewer days in the following two years. The first figure may be biased by the fact that some training courses might still have been in session during the first sampling period, but the difference in the later period cannot be so easily dismissed. Moreover, although the average monthly earnings of trainees eventually increased by $\$ 908$ (compared to the baseline) after an initial dip in the first year, the improvement is still $\$ 400$ less than the comparable figure for the comparison group, suggesting little (even negative) value added for retraining. None of these "difference in difference" estimates are statistically significant due, perhaps, to the small sample size, but they surely do not offer any evidence of an effective retraining effort.

A more subjective assessment of the effectiveness of retraining is provided by the trainees' comments on the relevance of the skills they learned to their current or last employment. It can be seen in table 4 that less than 46 percent of the trainees actually found skills acquired from retraining useful for their job, while more than 35 percent reported that they never used those skills. There is also some indication that full-time and specific skills courses tended to be more effective in training skills that were subsequently used.

Although the results in this section offer a general assessment of the effectiveness of the retraining programme, they can be misleading. Obvious differences exist between the observable characteristics of the treatment and comparison groups, and unobservable attributes may also differ as a result of self-selection into the respective groups. Simple 
comparisons between performance measures may just reflect the effects of these differences. In the following sections, we shall try to control statistically for observable and unobservable differences between the groups.

\section{B. Fixed-effects models of earnings}

Among the different measures of the training effect, change in earnings is perhaps the most studied. Standard models have been developed, including the fixed-effects models specified in equations (2) and (3). In estimating equation (2), earnings from the current or last job is regressed on a programme-participation dummy, two time dummies (one for each posttraining survey), as well as linear and quadratic terms of years of work experience; all time invariant demographic attributes are absorbed into the intercept. In the programme interaction-effect model (equation 3), the programme participation dummy is interacted with subject characteristics (gender, education, experience, experience squared, and industry/occupation of previous employment) and course characteristics (whether training is full-time or part-time, and whether training is in general or specific skills) in order to investigate the differential effects of different types of training on different groups. The results, for different data panels are reported in table 5.

Columns (1), (3) and (5) indicate that controlling for differences in the subjects' attributes does not substantially change our finding in the last section: skills training is almost always associated with lower earnings, even though the earnings differences are usually dominated by within group variation and therefore statistically insignificant. The earnings effect of training also differs across groups. The coefficients on the interactions terms in columns (2), (4) and (6) suggest that previous production workers with lower education appear to benefit more from skills training. This is due perhaps to their lower baseline earnings, which would accentuate improvements even if the same training brings the same 
employment opportunities, particularly if these opportunities do not require much formal education. The treatment effect on female trainees, who were over-represented in the treatment group, was on average $\$ 1439$ a month higher relative to the treatment effect on men one year after training. This is consistent with extensive foreign experience. However, the advantage all but dissipated after three years. Hong Kong-born manufacturing workers also tend to benefit less from earnings, but the difference is not significant.

Different types of training courses also tend to differ in their effectiveness. Full-time training fared slightly worse than part-time training. More importantly, general-skills courses were significantly less effective than specific-skills training in enhancing earnings, particularly in the long run. Considering that 60 percent of the sample enrolled in generalskills courses, this would have a significant negative effect on the overall efficiency of the programme.

\section{Days of Employment}

In estimating the tobit model of duration of employment, we use basically the same set of independent variables as in the earnings model, except that education, gender, and the number of small children (less than 6 years old) are explicitly controlled for. Estimation results are given in table 6. From columns (1), (3) and (5), it can be seen that older and female workers with small children worked significantly fewer days over different periods, which is not unexpected, but education and training basically had no effect. The models with interaction terms again reveal that different types of training had different effects on different subjects. In particular, full-time and general skills training is again found to have significantly reduced the duration of employment. On the other hand, contrary to previous results on earnings, training is found to have benefitted production workers by less, probably reflecting a greater difficulty for these workers to find employment in a service-oriented economy. 
The estimates of the training effect in columns (1) to (4) may potentially be biased downward because, as mentioned earlier, the training courses were still in session when the baseline survey was conducted. This is particularly the case for full-time trainees. But if we focus on columns (5) and (6), which cover a 2-year period long after the completion of training, the same qualitative results still obtain. The variation in training effects across trainees and course types is actually quite remarkable. Trainees who were originally production workers worked 106 fewer days over the two years between the last two waves of survey, compared to non-production workers, while graduates of full-time and general skills courses worked 153 and 161 fewer days respectively than other trainees. Given the insignificant overall programme effect, it would imply that specific skills and part-time training can actually increase employment duration, particularly for non-production workers.

\section{Random-effects Probit models of employment rate}

Retraining is expected to increase employability, thereby raising the employment rate among trainees. To investigate whether this is in fact the case, we estimate probit models of employment status implied by equations (4) and (5). The results are summarized in table 7.

The demographic variables in the simple model (columns (1), (3) and (5)) generally show the expected effects on employment status. Older workers, or women (particularly those with young children) have lower employment rates, reflecting perhaps a higher likelihood of withdrawal from the labour force. Higher education is seen to reduce the probability of employment, but the effect is not significant. Most importantly, contrary to the government's repeated assertions, we find no evidence that retraining raises employment prospects once characteristics of the trainees have been taken into account. Training does seem to be a slightly more positive effect in the long run than in the short run, but the estimate is still small in magnitude and statistically insignificant. 
The corresponding programme interaction-effect model provides some hints as to why this is the case (see columns (2), (4) and (6)). In the short run, training works less well in raising employment chances for women, older workers, and production workers, while general skills courses are again found to be less effective than specific training. With an overrepresentation of female and general skills trainees in the treatment group, it is not surprising that the short-run average training effect on employment probability is negative. The gender (and the age) effect on training diminished over time, but the lower effectiveness of general training persisted three years after the completion of training, bringing down the long run employment rate of the trainees. The results also show that training does not improve the chance of employment for production workers, which is consistent with our earlier findings on fewer days of work for these workers.

If training is supposed to raise the employment rate, then it is also supposed to reduce unemployment among the trainees. However, whether a worker in the labour force can escape unemployment depends more on her employability than on her labour supply decision. Accordingly, in applying equation (4) and (5) to post-training unemployment status, we use the human capital variables that are included in the earnings models, together with the dummy variables for time and programme participation. ${ }^{4}$ The results, in table 8 , show that, as expected, unemployment is higher among women and older workers. Higher education and participation in training actually tend to raise the probability of unemployment, although the effects are not significant. The coefficients on the interaction terms in column (2) show that different types of training are equally ineffective in reducing unemployment, regardless of the characteristics of the trainees.

${ }^{4}$ Only data from the baseline and the last wave of survey are used because questions on job search activities were not asked in the 1-year follow-up survey. 
To briefly recapitulate, we find no evidence that skills training financed by the Employees Retraining Board during the sampling period has had any positive effect on outcome measures. Trainees performed uniformly worse, if insignificantly so, than comparison subjects in employment rate, unemployment rate, days of employment, and earnings. While the effectiveness of training might have varied across individuals with different characteristics, the most consistent finding is the relative inefficiency of general skills training and, to an extent, full-time training. The poor performance of these types of training courses accounts for much of the failure of the retraining programme to bring about any real improvement in the labour market performance of the trainess.

\section{E. Specification Tests}

Our approach to measuring training effects is basically a before-and-after experiment. We measure how changes in a person's labour market outcomes are related to whether she received training in the intervening period. An implicit assumption of this approach is that the treatment group and the comparison group would not have experienced systematically different changes in labour market outcomes but for the change in the amount of training they received. Given the obvious differences in the characteristics of the treatment and the comparison groups in table 2, one cannot be sure of the validity of this key assumption.

Whether the assumption holds or not can be tested by "post-programme tests" (Heckman and Hotz 1989). In the case of employment earnings, the post-programme test is performed by estimating equations (2) and (3), using data from the two follow-up surveys only. ${ }^{5}$ If the treatment group and the comparison group are not systematically different, the

${ }^{5}$ In performing the post-programme test, the training variable is coded 0 for wave 3 observations and is coded 1 for wave 4 observations for the treatment group. This variable is equal to 0 for all subjects in the comparison group. 
coefficients on the training variables should be jointly insignificant. As shown in the first row of table 9, the maintained assumption of no statistical difference between treatment group and comparison group is not rejected by the post-programme data. A similar exercise on employment status, as modeled by equations (4) and (5), also fails to reject the maintained assumption (see the second row of table 9). Therefore, we can conclude that, despite the apparent differences between the treatment and comparison groups, our statistical models present a reasonable framework for the evaluation of the effectiveness of the retraining programme.

\section{Conclusion and Policy Implications}

The Employees Retraining Programme is one of the most important labour policy initiatives of the Hong Kong government, touted at one time or another as the solution to structural unemployment arising from economic transformation, as well as to escalating cyclical unemployment in the aftermath of the Asian financial crisis. Unfortunately, in this evaluation, we find little evidence to support such high expectations. Survey data we collected from 1995 to 1999 consistently show that the programme fails to bring about any improvement in labour market performance of the trainees relative to a comparison group of job seekers in terms of employment rate, unemployment rate, days of employment, and earnings, particularly in the long run. If anything, our findings suggest a small but insignificant advantage in favour of the comparison group. Without any positive result to show for the substantial investment, the Employees Retraining Programme can hardly be considered a success.

Despite the disappointing results we found within the horizon of this study, the government can yet pin its hope on better performance of the trainees further down the road. 
It is not clear how well performance two or three years after training can be extrapolated to predict outcomes over the longer run, because few evaluation studies have actually tracked performance beyond three years. One exception is Ashenfelter (1980), who uses Social Security data to trace earnings for classroom trainees under the Manpower Development and Training Act (MDTA) and a comparison group from 1959 to 1969. His estimates show that much of the earnings gain resulting from training accrued in the first two or three years, with little or no further improvements subsequently. In fact, for male trainees, the treatment effect began to wear off after two years. White females were the only demographic group showing a modest but continued growth in advantage five years after training. This finding is corroborated by a more recent study by Couch (1992), who finds that while short-run earnings effect of the National Supported Work experiment did not last beyond the first few years after training for disadvantaged youth, the earnings gain enjoyed by disadvantaged women persisted in the long run, and was actually larger four to eight years after the completion of training than in the first three years.

These observations might suggest some basis for optimism for the Hong Kong programme, given the predominance of women among trainees. However, our results in table 5 show that even the initially positive training effect on earnings for female trainees has reversed direction by the third year after training, indicating that the U.S. observations on white females may not be an appropriate example. ${ }^{6}$ Moreover, most trainees in the Hong Kong programme were trained in general (language and computer) skills that depreciate quickly over time with the lack of use. This makes it unlikely that poor performance in the

${ }^{6}$ Actually, Couch (1992) also found that the earnings effect of training on disadvantaged women also diminished in the second and third year before increasing again. However, he attributes this aberration to data quality problems specific to those years. There is no reason to believe that such is the also the case in our study. 
first three years would be offset by better performance in the long run. In fact, the only improvement over time that we can detect from our data is an increase in the training effect on employment rates over the longer run (table 7), but even in this case, the magnitude of the effect remains small and we cannot conclude that training increases the probability of employment. The fact that training has not increased the duration of employment between the two post-training surveys also suggests that it is not advisable to read too much into the observation. Therefore, on the basis of our findings, it would be unrealistic to expect any substantial sign of improvement in the long run even if this survey is repeated in the future.

There are also some sporadic evidence that retraining works better for some individuals than for others. However, given that the programme is intended to help those in need, it would be difficult for the government to reduce service to workers who benefit less from training, even if a more consistent pattern can be established. What it can do to improve efficiency of the programme is to focus resources on the courses that have higher valueadded. Intensity of training appears not to be a key factor affecting outcome. Despite the fact that subjects tend to find full-time training more effective in imparting skills that are relevant to their employment, there is no evidence that such training actually works better. In fact, it is found to be less effective than part-time training in improving the labour market performance of trainees, particularly in days of employment. Unfortunately, these full-time courses are also the most expensive to finance. Not only do they require more training resources, but they also offer an allowance of up to HK\$4,000 (approximately US\$510) a month for the trainees. ${ }^{7}$ There are, therefore, clear financial incentives both for training bodies to offer such courses and for trainees to oversubscribe to them, creating further pressure for expansion. The

${ }^{7}$ In the fiscal year 1995/6, allowance for trainees constituted 20 percent of the total retraining programme outlay. 
resulting diminishing returns are reflected in the low efficiency of these courses. Moreover, full-time training encourages trainees to withdraw from the labour force while undergoing training. Very often, this would simply delay unemployment, with possible employment opportunities being passed up. In view of the ineffectiveness of full-time training and the opposition of unionists to reduce allowance for full-time trainees, it would perhaps be advisable for the government to assign higher priority to part-time training in the future.

Equally important, if not more so, is our finding that general skills training consistently shows lower effectiveness than specific skills training by all measures of outcome, usually significantly so. The intent of these courses is to facilitate the transition of former manufacturing workers to more service-oriented employment, but this rather generalized approach does not seem to be working. The problem is that many subjects might have taken these courses with neither clear career objectives, nor an understanding of how such training would help them achieve those objectives. Therefore, providing training on these depreciable skills to a wide population with the hope that some may eventually benefit is not a very efficient use of resources, particularly when these courses represent the majority of the courses financed by the government. Apparently, a clearer focus and a greater emphasis on more specific aspects of career enhancement are necessary if such training is to be effective.

This study is only a partial evaluation of the long-term effectiveness of government's Employees Retraining Programme, covering only the skills training courses for general workers. But in terms of trainee intake, the courses represented 80 percent of the Programme's offerings at the time of the baseline survey. The failure of these courses to show any value added in general, and the low efficiency of certain types of training in particular, suggest serious problems in the retraining effort in Hong Kong. The efficiency of a 
programme of this nature would inevitably be constrained by many ethical, social and political considerations, but the fact that, when put in an international perspective, our findings tend to gravitate towards the low end of the estimates of programme effectiveness indicates that there is probably much room for improvement in its implementation in Hong Kong.

The success of the retraining initiative is important. With the permanent decline in the manufacturing base in the local economy, there is little hope that many of the victims of sectoral shifts would be able to find employment in their original industry and occupation. Just as it would be futile to try to reverse the process of economic transformation and bring back the industries that have lost competitiveness in Hong Kong, funneling resources into an inefficient retraining programme does not offer a real solution. Without an effective remedy, many, particularly older and less educated workers, may find themselves trapped in long-term unemployment and poverty. Given the potential magnitude of the social problem and the huge amount of retraining resources at stake, it is perhaps time for the government to reexamine its strategy. 


\section{References}

Ashenfelter, Orley. "Estimating the Effect of Training Programs on Earnings." The Review of Economics and Statistics 60 no.1 (January 1978): 47-57.

Ashenfelter, Orley, and David Card. "Using the Longitudinal Structure of Earnings to Estimate the Effect of Training Programs." Review of Economics and Statistics 67 (1985): 648-60.

Barnow, Burt S. "The Impact of CETA Programs on Earnings: A Review of the Literature." Journal of Human Resources 22 (1987): 157-93.

Bassi, Laurie J. "The Effect of CETA on the Postprogram Earnings of Participants," The Journal of Human Resources, 18 (1984): 540-556.

Bell, Stephen, John Enns, and Larry Orr. "The Effects of Job Training and employment on the Earnings and Public Benefits of AFDC Homemaker - Home Health Aid Demonstrations." Abt Associates, Inc., December 1987.

Blau, Francine D., and Kahn, Lawrence M. "International Differences in Male Wage Inequality: Institutions versus Market Forces." Journal of Political Economy 104 (August 1996): 791--837.

Bloom, Howard, and Maureen McLaughlin. "CETA Training Programs: Do They Work for Adults?" Joint CBO-NCEP Report, 1982.

Burghardt, John, et al. "Evaluation of the Minority single Parent Demonstration: Volume I: Summary," Mathematical Policy Research, Inc., October 1992.

Chan, William, and Suen, Wing. "An Evaluation of the Hong Kong Employees Retraining Programme." Working paper, University of Hong Kong, October 1999.

Couch, Kenneth. " New Evidence on the Long-Term Effects of Employment and Training Programs." Journal of Labor Economics 10 (October 1992): 380-8.

Dickinson, Katherine, Terry Johnson, and Richard West. "An Analysis of the Impact of CETA on Participants' Earnings," Journal of Human Resources 21(1986): 64-91.

Finifter, David H. "An Approach to Estimating Net Earnings Impact of Federally Subsidized Employment and Training Programs," Evaluation Review 11 (1987): 528-47.

Fracker, Thomas, and Rebecca Maynard. "Evaluating Comparison Group Designs with Employment-Related Programs," Journal of Human Resources 22 (1987): 194-227.

Friedlander, Daniel, and Judith M. Gueron. "Are High-Cost Services More Effective than Low-Cost Services?" In Charles Manski and Irwin Garfinkel (ed.), Evaluating Welfare and Training Programs. Cambridge, Mass.: Harvard University Press, 1992. 
Friedlander, Daniel, James Riccies, and stephen Freedman. "GAIN: Two Year Impacts in Six Counties." New York: Manpower Demonstration Research Corportation, May 1993.

Gay, Robert, and Michael Borus. "Validating Performance Indicators for employment and Training Programs." Journal of Human Resources 15 (1980): 29-48.

Geraci, Vincent. "Short-Term Indicators of Job Training Program Effects on Long-Term Participant Earnings," Report prepared for U.S. Department of Labor under Contract No. 20-48-82-16 (1984).

Heckman, James J., and V. Joseph Hotz. "Choosing Among Alternative Nonexperimental Methods for Estimating the Impact of Social Programs: The Case of Manpower Training." Journal of American Statistical Association 84 (1989): 862-74.

Heckman, James J., and Richard Robb, Jr. "Alternative Methods for Evaluating the Impact of Interventions." In James Heckman and Burton Singer (ed.) Longitudinal Analysis of Labor Market Data. New York: Cambridge University Press, 1985.

Hotz, Joseph V. "Designing an Evaluation of the Job Training Partnership Act." In Charles Manski and Irwin Garfinkel (ed.), Evaluating Welfare and Training Programs. Cambridge, Mass.: Harvard University Press, 1992.

Juhn, Chinhui. "Decline of Male Labor Market Participation: The Role of Declining Market Opportunities." Quarterly Journal of Economics 107 (February 1992): 79--121.

, Murphy, Kevin M., and Pierce, Brooks. "Wage Inequality and the Rise in Returns to Skill." Journal of Political Economy 101 (June 1993): 410--442.

Katz, Lawrence F., Loveman, Gary W., and Blanchflower, David G. "A Comparison of Changes in the Structure of Wages in Four OECD Countries." In Differences and Changes in Wage Structure, edited by Richard B. Freeman and Lawrence F. Katz. Chicago: University of Chicago Press, 1995.

LaLonde, Robert. "Evaluating the Econometric Evaluations of Training Programs with Experimental Data." American Economic Review 76 (1986): 604-20. and Rebecca Maynard. "How Precise Are the Evaluations of Employment and Training Programs: Evidence from a Field Experiment," Evaluation Review 11 (1987): 428-51.

Suen, Wing. "Sectoral Shifts: Impact on Hong Kong Workers." Journal of International Trade and Economic Development 4 (July1995): 135--152.

Westat. "Summary of Net Impact Results," Report prepared for the U.S. Department of Labor under Contract No. 23-24-75-07, 1981. 
Table 1

Distribution of Skills Treatment Subjects by Types of Courses

Full-day course Evening course Half-day course Total

General skills

76

206

120

402

Specific skills

156

82

34

272

Total

232

288

154

674 
Table 2

Summary Statistics (at the baseline)

N
Age
Sex $(\%$ F)
Education
Place of Birth $(\% \mathrm{HK})$
Marital Status $(\%)$
$\quad$ single
married
widowed
divorced
No. of children a
Housing $(\%)$
$\quad$ public rented
public owned
private rented
private owned
other
Breadwinner $(\%)$
Public Assist. $(\%)$
No. of household members
Manufacturing workers $(\%)$
Production workers $(\%)$
Potential experience
Actual experience

${ }^{a}$ Averaged across non-single subjects.
Treatment Group

674

40.75

93.75

9.36

76.68

18.15

77.53

1.64

2.68

1.88

41.58

22.00

7.74

27.31

1.37

28.66

3.00

3.73

42.57

28.09

25.42

20.24
Comparison Group

185

42.59

54.05

7.62

48.60

14.59

82.16

1.08

2.16

2.14

65.54

10.73

11.30

11.86

0.56

62.09

4.92

4.26

32.04

34.97

29.02

22.94 
Table 3

\section{Labour Market Performance: Skills Trainees vs Comparison Group}

(1)

Skills Trainees
(2)

Labour Dept

Registrants

Employment rate

(A) January - February 1996

(B) January - March 1997

(C) April-May 1999

(B) - (A)

(C) - (A)

\section{Work Hours}

(D) January - February 1996

(E) January - March 1997

(F) April-May 1999

(E) - (D)

(F) - (D)

Duration of employment from January 1996 to Jan 1997

Duration of employment from January 1997 to April 1999

Earnings at current or last job

(G) January - February 1996

(H) January - March 1997

(I) April-May 1999

$$
\begin{gathered}
.4234 \\
(.0192) \\
.6126 \\
(.0189) \\
.6186 \\
(.0188) \\
.1892 \\
(.0195) \\
.1952 \\
(.0218)
\end{gathered}
$$

42.09

(.7069)

43.14

(.6892)

44.43

(.6963)

1.052

(.6894)

2.346

(.7649)

201.9

(5.905)

469.5

(12.54)

6527

(219.4)

6451

(157.4)

7436

(183.7)

$\begin{array}{cc}.4919 & -.0685 \\ (.0369) & (.0412) \\ & -.0901 \\ .7027 & (.0400) \\ (.0337) & -.0462 \\ .6649 & (.0402) \\ (.0348) & -.0216 \\ .2108 & (.0445) \\ (.0469) & .0222 \\ .1730 & (.0468) \\ (.0414) & \end{array}$

51.37

(1.572)

$-9.281$

(1.494)

50.40

(1.519)

$-7.258$

(1.449)

50.73

$-6.298$

(1.468)

(1.430)

$-.9717$

2.023

(2.154)

(1.805)

$-.6368$

2.983

(1.635)

221.6

$-19.68$

(12.43)

509.5

$-40.02$

(23.14)

(26.84)

60.09

6467

(437.3)

(313.7)

$-248.6$

6700

(335.8)

$-338.5$

7774

(381.2) 


$\begin{array}{cccc}\text { (H) }-(\mathrm{G}) & -76.12 & 232.6 & -308.7 \\ & (195.2) & (411.2) & (422.3) \\ \text { (I) }-(\mathrm{G}) & 908.4 & 1307 & -398.6 \\ & (220.6) & (329.6) & (442.6)\end{array}$

\section{Unemployment Rate}

(J) January - February 1996

.4677

(.0218)

.4270

.0407

(.0365)

(.0426)

(K) April-May 1999

.2205

(.0181)

.2054

.0151

(.0298)

(.0353)

(K) - (J)

$-.2471$

(.0247)

$-.2216$

(.0420)

$-.0255$

(.0485) 
Table 4

Job-relevance of Training as Reported by Trainess

\section{A. By Course Intensity}

$\begin{array}{llllll} & \begin{array}{l}\text { Not relevant } \\ \text { at all }\end{array} & \begin{array}{l}\text { Not very } \\ \text { relevant }\end{array} & \begin{array}{l}\text { Somewhat } \\ \text { relevant }\end{array} & \begin{array}{l}\text { Very } \\ \text { relevant }\end{array} & \text { Total } \\ \begin{array}{l}\text { Full time } \\ \text { course }\end{array} & 52 & 34 & 40 & 48 & 174 \\ \begin{array}{l}\text { Evening } \\ \text { course }\end{array} & 89 & 48 & 54 & 53 & 244 \\ \begin{array}{l}\text { Half-day } \\ \text { course }\end{array} & 36 & 15 & 16 & 18 & 85 \\ \text { Total } & 177 & 97 & 110 & 119 & 503\end{array}$

\section{B. By Course Content}

$\begin{array}{llllll} & \begin{array}{l}\text { Not relevant } \\ \text { at all }\end{array} & \begin{array}{l}\text { Not very } \\ \text { relevant }\end{array} & \begin{array}{l}\text { Somewhat } \\ \text { relevant }\end{array} & \begin{array}{l}\text { Very } \\ \text { relevant }\end{array} & \text { Total } \\ \begin{array}{l}\text { General skills } \\ \text { courses }\end{array} & 103 & 53 & 60 & 62 & 278 \\ \begin{array}{l}\text { Specific skills } \\ \text { course }\end{array} & 74 & 44 & 50 & 57 & 225 \\ \begin{array}{l}\text { Total } \\ \text { Total }\end{array} & 177 & 97 & 110 & 119 & 503\end{array}$


Table 5

Fixed-effect Models of Earnings

\section{Waves I and III}
(1)
(2)

$-1030$

(471.9)

$-1659$

(525.0)

Wave4

Skills

Experience

Experience $^{2}$

Female $\times$ Skills

Education $\times$ Skills

Experience $\times$ Skills

Experience $^{2} \times$ Skills

Hong Kong born $\times$ Skills

Manufacturing $\times$ Skills

Production $\times$ Skills

Full-time

Skills

General

Skills

Constant

$\mathrm{n}$

$\mathrm{F}$ for $\mathrm{H}_{0}: \theta=0$

$($ Prob > F)
Waves I and IV

(3)

(4)

(5)

$-440.0$

(268.0)

$-754.8$

(457.3)

$-313.5$

(276.0)

(385.5)

1030

(236.0)

(322.9)

$-2.502$

$-4.118$

(3.544)

(4.051)

(5.689)

$-586.6$

(765.9)

$-309.8$

(102.2)

17.75

(144.6)

$-1.278$

(3.096)

$-605.6$

(503.1)

$-452.7$

(502.4)

1047

(571.0)

$-75.34$

(468.3)

$-974.9$

(424.4)

$-13442$

(5025.3)

$-13408$

(3882.9)

576

666
(6)

$-547.3$

(278.9)

$-972.3$

(489.3)

$-19.87$

(296.9)

1156

(264.5)

(4.316)

222.1

(594.3)

$-244.7$

(78.42)

$-78.21$

(102.2)

1.123

(2.236)

$-502.1$

(390.8)

$-340.6$

(398.0)

889.1

(453.0)

$-193.7$

(367.1)

$-904.2$

(337.8)

$-16063$

(4261.9)

2.89

(.0023)

Note: $\quad$ Skills is a dummy which equals 1 if the subject receives skills training; Wave3 (Wave4) is a dummy for observations in Wave 3 (Wave 4) survey; experience is the number of years of work experience; female is a dummy which equals 1 if the subject is female; Hong Kong born is a dummy which equals 1 if the subject was born in Hong Kong; Manufacturing (Production) is a dummy which equals 1 if the subject current/last job is in manufacturing (production); Full-time Skills (General Skills) is a dummy which equals 1 if the subject received full-time (general) skills training; AgexSkills is the interaction term between the variable Age and the Skills dummy, etc. 


\section{Table 6}

Tobit Models of Employment Duration

\section{Waves I and III}

(1) (2)

\section{Waves I and IV}

(3)

(4)

Waves III and IV

\begin{tabular}{|c|c|c|c|c|c|c|}
\hline Skills & $\begin{array}{l}-1.217 \\
(19.52)\end{array}$ & $\begin{array}{c}18.54 \\
(19.48)\end{array}$ & $\begin{array}{l}-12.92 \\
(47.47)\end{array}$ & $\begin{array}{c}39.64 \\
(47.53)\end{array}$ & $\begin{array}{l}-1.374 \\
(40.91)\end{array}$ & $\begin{array}{c}36.57 \\
(41.95)\end{array}$ \\
\hline Age & $\begin{array}{l}-3.661 \\
(1.098)\end{array}$ & $\begin{array}{c}-.4332 \\
(1.671)\end{array}$ & $\begin{array}{l}-13.37 \\
(2.679)\end{array}$ & $\begin{array}{l}-7.773 \\
(4.099)\end{array}$ & $\begin{array}{l}-11.39 \\
(2.330)\end{array}$ & $\begin{array}{l}-7.838 \\
(3.627)\end{array}$ \\
\hline Education & $\begin{array}{l}-.1295 \\
(2.757)\end{array}$ & $\begin{array}{l}-3.140 \\
(3.966)\end{array}$ & $\begin{array}{l}-2.392 \\
(6.697)\end{array}$ & $\begin{array}{l}-8.315 \\
(9.683)\end{array}$ & $\begin{array}{l}-1.699 \\
(5.786)\end{array}$ & $\begin{array}{l}-4.711 \\
(8.569)\end{array}$ \\
\hline Female & $\begin{array}{l}-83.36 \\
(21.78)\end{array}$ & $\begin{array}{l}-62.41 \\
(27.40)\end{array}$ & $\begin{array}{l}-208.1 \\
(53.35)\end{array}$ & $\begin{array}{l}-171.9 \\
(67.09)\end{array}$ & $\begin{array}{l}-152.5 \\
(45.88)\end{array}$ & $\begin{array}{l}-141.3 \\
(59.34)\end{array}$ \\
\hline Small kids & $\begin{array}{l}-50.69 \\
(15.03)\end{array}$ & $\begin{array}{l}-34.30 \\
(15.15)\end{array}$ & $\begin{array}{l}-146.4 \\
(36.51)\end{array}$ & $\begin{array}{l}-122.6 \\
(37.06)\end{array}$ & $\begin{array}{l}-112.5 \\
(31.77)\end{array}$ & $\begin{array}{l}-104.7 \\
(33.09)\end{array}$ \\
\hline Female $\times$ Skills & - & $\begin{array}{l}-29.77 \\
(41.19)\end{array}$ & - & $\begin{array}{l}-46.62 \\
(101.4)\end{array}$ & - & $\begin{array}{l}-9.088 \\
(89.56)\end{array}$ \\
\hline Education $\times$ Skills & - & $\begin{array}{c}4.819 \\
(5.514)\end{array}$ & - & $\begin{array}{c}15.34 \\
(13.48)\end{array}$ & - & $\begin{array}{c}11.18 \\
(11.97)\end{array}$ \\
\hline Agex Skills & - & $\begin{array}{l}-4.873 \\
(2.091)\end{array}$ & - & $\begin{array}{l}-8.517 \\
(5.121)\end{array}$ & - & $\begin{array}{l}-5.552 \\
(4.551)\end{array}$ \\
\hline $\begin{array}{l}\text { Manufacturing × } \\
\text { Skills }\end{array}$ & - & $\begin{array}{l}-10.19 \\
(20.26)\end{array}$ & - & $\begin{array}{l}-7.783 \\
(49.54)\end{array}$ & - & $\begin{array}{c}6.597 \\
(43.21)\end{array}$ \\
\hline Production $\times$ Skills & - & $\begin{array}{l}-64.22 \\
(22.51)\end{array}$ & - & $\begin{array}{l}-150.0 \\
(54.84)\end{array}$ & - & $\begin{array}{l}-106.6 \\
(47.96)\end{array}$ \\
\hline $\begin{array}{l}\text { Full-time } \\
\text { Skills }\end{array}$ & - & $\begin{array}{l}-117.7 \\
(18.22)\end{array}$ & - & $\begin{array}{l}-245.6 \\
(44.29)\end{array}$ & - & $\begin{array}{l}-153.4 \\
(39.21)\end{array}$ \\
\hline $\begin{array}{l}\text { General } \\
\text { Skills }\end{array}$ & - & $\begin{array}{l}-53.70 \\
(17.41)\end{array}$ & - & $\begin{array}{l}-184.9 \\
(42.49)\end{array}$ & - & $\begin{array}{l}-160.6 \\
(37.45)\end{array}$ \\
\hline Constant & $\begin{array}{c}416.6 \\
(59.38)\end{array}$ & $\begin{array}{c}292.3 \\
(89.82)\end{array}$ & $\begin{array}{c}1453 \\
(144.7)\end{array}$ & $\begin{array}{c}1243 \\
(219.9)\end{array}$ & $\begin{array}{c}1077 \\
(125.8)\end{array}$ & $\begin{array}{c}948.4 \\
(194.6)\end{array}$ \\
\hline $\mathrm{n}$ & 815 & 704 & 815 & 704 & 826 & 711 \\
\hline Pseudo $\mathrm{R}^{2}$ & .0037 & .0113 & .0042 & .0093 & .0039 & .0078 \\
\hline $\begin{array}{l}\mathrm{F} \text { for } \mathrm{H}_{0}: \theta=0 \\
(\text { Prob }>\mathrm{F})\end{array}$ & - & $\begin{array}{c}9.38 \\
(.0000)\end{array}$ & - & $\begin{array}{c}7.77 \\
(.0000)\end{array}$ & - & $\begin{array}{c}4.90 \\
(.0000)\end{array}$ \\
\hline
\end{tabular}

Note: Small kids is the number of the subject's children who are less than 6 years old. Other variables are explained in the note for table 5 . 
Table 7

Random-effect Probit Models of Employment Status

$\begin{array}{lllllr}\begin{array}{l}\text { Waves I } \\ \text { and III }\end{array} & \begin{array}{l}\text { Waves I } \\ \text { and III }\end{array} & \begin{array}{l}\text { Waves I } \\ \text { and IV }\end{array} & \begin{array}{l}\text { Waves I } \\ \text { and IV }\end{array} & \begin{array}{c}\text { Waves I, } \\ \text { III and IV }\end{array} & \begin{array}{r}\text { Waves I, } \\ \text { III and IV }\end{array}\end{array}$
(1)
(2)
(3)
(5)
(6)

\begin{tabular}{|c|c|c|c|c|c|c|}
\hline Wave3 & $\begin{array}{c}.5935 \\
(.0989)\end{array}$ & $\begin{array}{c}.5527 \\
(.1013)\end{array}$ & - & - & $\begin{array}{c}.5510 \\
(.0846)\end{array}$ & $\begin{array}{c}.5009 \\
(.0884)\end{array}$ \\
\hline Wave4 & - & - & $\begin{array}{c}.5560 \\
(.1019)\end{array}$ & $\begin{array}{c}.5109 \\
(.1039)\end{array}$ & $\begin{array}{c}.5980 \\
(.0864)\end{array}$ & $\begin{array}{c}.5554 \\
(.0899)\end{array}$ \\
\hline Skills & $\begin{array}{l}-.1027 \\
(.1075)\end{array}$ & $\begin{array}{l}-1.768 \\
(1.060)\end{array}$ & $\begin{array}{c}.0233 \\
(.1088)\end{array}$ & $\begin{array}{c}.0557 \\
(.1160)\end{array}$ & $\begin{array}{l}-.0406 \\
(.0865)\end{array}$ & $\begin{array}{c}.0018 \\
(.0928)\end{array}$ \\
\hline Age & $\begin{array}{l}-.0208 \\
(.0060)\end{array}$ & $\begin{array}{l}-.0147 \\
(.0070)\end{array}$ & $\begin{array}{l}-.0276 \\
(.0059)\end{array}$ & $\begin{array}{l}-.0254 \\
(.0070)\end{array}$ & $\begin{array}{l}-.0249 \\
(.0056)\end{array}$ & $\begin{array}{l}-.0205 \\
(.0067)\end{array}$ \\
\hline Education & $\begin{array}{l}-.0109 \\
(.0144)\end{array}$ & $\begin{array}{l}-.0213 \\
(.0168)\end{array}$ & $\begin{array}{l}-.0212 \\
(.0143)\end{array}$ & $\begin{array}{l}-.0226 \\
(.0167)\end{array}$ & $\begin{array}{l}-.0106 \\
(.0134)\end{array}$ & $\begin{array}{l}-.0168 \\
(.0161)\end{array}$ \\
\hline Female & $\begin{array}{l}-.4876 \\
(.1115)\end{array}$ & $\begin{array}{l}-.3493 \\
(.1198)\end{array}$ & $\begin{array}{l}-.4628 \\
(.1097)\end{array}$ & $\begin{array}{l}-.3978 \\
(.1196)\end{array}$ & $\begin{array}{l}-.4969 \\
(.1053)\end{array}$ & $\begin{array}{l}-.3986 \\
(.1153)\end{array}$ \\
\hline Small kids & $\begin{array}{l}-.2597 \\
(.0814)\end{array}$ & $\begin{array}{l}-.2211 \\
(.0894)\end{array}$ & $\begin{array}{l}-.3079 \\
(.0803)\end{array}$ & $\begin{array}{l}-.2931 \\
(.0888)\end{array}$ & $\begin{array}{l}-.2817 \\
(.0751)\end{array}$ & $\begin{array}{l}-.2620 \\
(.0824)\end{array}$ \\
\hline Female $\times$ Skills & - & $\begin{array}{l}-.4163 \\
(.2589)\end{array}$ & - & $\begin{array}{l}-.0067 \\
(.2409)\end{array}$ & - & $\begin{array}{l}-.1789 \\
(.2003)\end{array}$ \\
\hline $\begin{array}{l}\text { Education } \times \\
\text { Skills }\end{array}$ & - & $\begin{array}{c}.0439 \\
(.0278)\end{array}$ & - & $\begin{array}{c}.0263 \\
(.0280)\end{array}$ & - & $\begin{array}{c}.0320 \\
(.0228)\end{array}$ \\
\hline Age $\times$ Skills & - & $\begin{array}{l}-.0164 \\
(.0098)\end{array}$ & - & $\begin{array}{l}-.0038 \\
(.0099)\end{array}$ & - & $\begin{array}{l}-.0088 \\
(.0080)\end{array}$ \\
\hline $\begin{array}{l}\text { Manufacturing } \times \\
\text { Skills }\end{array}$ & - & $\begin{array}{c}.0528 \\
(.1381)\end{array}$ & - & $\begin{array}{c}.1066 \\
(.1388)\end{array}$ & - & $\begin{array}{c}.0798 \\
(.1097)\end{array}$ \\
\hline $\begin{array}{l}\text { Production } \times \\
\text { Skills }\end{array}$ & - & $\begin{array}{l}-.3534 \\
(.1514)\end{array}$ & - & $\begin{array}{l}-.2732 \\
(.1521)\end{array}$ & - & $\begin{array}{l}-.3067 \\
(.1201)\end{array}$ \\
\hline Full-time Skills & - & $\begin{array}{l}-.1613 \\
(.1242)\end{array}$ & - & $\begin{array}{c}.0242 \\
(.1248)\end{array}$ & - & $\begin{array}{l}-.0517 \\
(.0986)\end{array}$ \\
\hline General Skills & - & $\begin{array}{l}-.3502 \\
(.1200)\end{array}$ & - & $\begin{array}{l}-.3339 \\
(.1199)\end{array}$ & - & $\begin{array}{l}-.3373 \\
(.0950)\end{array}$ \\
\hline Constant & $\begin{array}{c}1.266 \\
(.3305)\end{array}$ & $\begin{array}{c}1.061 \\
(.3786)\end{array}$ & $\begin{array}{c}1.627 \\
(.3271)\end{array}$ & $\begin{array}{c}1.566 \\
(.3802)\end{array}$ & $\begin{array}{c}1.442 \\
(.3080)\end{array}$ & $\begin{array}{c}1.309 \\
(.3658)\end{array}$ \\
\hline $\mathrm{n}$ & 1644 & 1421 & 1644 & 1421 & 2470 & 2132 \\
\hline $\begin{array}{l}\chi^{2} \text { for } \mathrm{H}_{0}: \theta=0 \\
\left(\text { Prob }>\chi^{2}\right)\end{array}$ & - & $\begin{array}{c}24.19 \\
(.0011)\end{array}$ & - & $\begin{array}{c}14.98 \\
(.0362)\end{array}$ & - & $\begin{array}{c}26.35 \\
(.0004)\end{array}$ \\
\hline
\end{tabular}


Table 8

\section{Random-effect Probit Models of Unemployment Status}

(2)

Wave4

$-.7004$

$(.1277)$

$-.6686$

$(.1311)$

Skills

.0323

(.1394)

.0608

$(.1479)$

Actual experience

$-.0354$

$(.0183)$

$-.0297$

(.0228)

Actual experience ${ }^{2}$

.0007

.0007

(.0004)

(.0004)

Education

.0245

.0347

(.0165)

(.0196)

Female

.2386

(.1207)

.2112

(.1325)

Hong Kong born

$-.0198$

.0767

(.0924)

(.1151)

Female $\times$ Skills

$-.2201$

(.2958)

Education $\times$ Skills

$-.0529$

(.0373)

Experience $\times$ Skills

.0044

(.0480)

Experience $^{2} \times$ Skills

$-.0002$

(.0010)

Hong Kong born $\times$ Skills

$-.2608$

(.1924)

Manufacturing $\times$ Skills

.1776

$(.1750)$

Production $\times$ Skills

.1641

(.1901)

Full-time Skills

$-.0266$

(.1599)

General Skills

.0475

(.1543)

Constant

$-.1972$

$-.4618$

(.2962)

(.3687)

1253

1115

$\chi^{2}$ for $\mathrm{H}_{0}: \theta=0$

(Prob $>\chi^{2}$ )

9.70

(.3756) 


\section{Table 9}

\section{Postprogramme Specification Tests}

\begin{tabular}{lll}
\hline Dependent variable & $\mathrm{H}_{0}: \delta=0$ & $\mathrm{H}_{0}: \theta=0$ \\
\hline Employment earnings & $\begin{array}{l}t=-0.711 \\
(p=0.477)\end{array}$ & $\begin{array}{l}F(9,364)=1.38 \\
(p=0.1968)\end{array}$ \\
Employment status & $\begin{array}{l}z=0.743 \\
(p=0.457)\end{array}$ & $\begin{array}{l}\chi^{2}(5)=9.22 \\
(p=0.2375)\end{array}$ \\
\hline
\end{tabular}

